\title{
Pengaruh Profitabilitas, Struktur Aktiva, Likuiditas, dan Ukuran Perusahaan Terhadap Struktur Modal (Pada Perusahaan Pertambangan yang Terdaftar di Bursa Efek Indonesia Tahun 2014-2018)
}

\author{
Umi Dwi Astuti ${ }^{1}$, Axel Giovanni ${ }^{2}$ \\ Program Studi Manajemen, Universitas Tidar Magelang ${ }^{1,2}$ \\ Email korespondensi: umidwiastuti22@gmail.com ${ }^{1}$, $\underline{\text { axelgiovanni@untidar.ac.id }}^{2}$
}

Received: 15 Feb $2021 \quad$ Reviewed: 3 Mar 2021 Accepted: 12 Mar $2021 \quad$ Published: 30 Apr 2021

\begin{abstract}
This study aims to see the effect of profitability, asset structure, liquidity, and company size on the capital structure of the mining companies listed on the Indonesian Stock Exchange in 20142018. Secondary data is used for the research and it is collected using purposive sampling. The data then analyzed using multiple linear regression. Research results shows that profitability and companies size have no effect on capital structure. Meanwhile, the asset structure and liquidity have effect on capital structure. The limitation of this study is the lack of a research period to the small sample used. Researcher's suggestion for further research is to increase the time period of the study, which is aimed to increase the accuracy of the research data.
\end{abstract}

Keywords: capital structure, profitability, asset structure, liquidity, company size

\begin{abstract}
ABSTRAK
Penelitian ini bertujuan untuk melihat pengaruh profitabilitas, struktur aktiva, likuiditas, dan ukuran perusahaan terhadap struktur modal pada sektor perusahaan pertambangan yang terdaftar di Bursa Efek Indonesia periode 2014-2018. Metode pengambilan data menggunakan purposive sampling menggunakan data sekunder. Data dianalisis dengan menggunakan dengan teknik analisis regresi linier berganda. Hasil penelitian menunjukkan profitabilitas dan ukuran perusahaan tidak berpengaruh terhadap struktur modal. Sedangkan untuk struktur aktiva dan likuiditas berpengaruh terhadap struktur modal. Keterbatasan penelitian adalah kurangnya periode penelitian dikarenakan sampel yang digunakan sedikit. Saran peneliti untuk penelitian selanjutnya ialah menambah periode waktu penelitian untuk meningkatkan keakuratan data penelitian.
\end{abstract}

Kata kunci: struktur modal, profitabilitas, struktur aktiva, likuiditas, ukuran perusahaan

\section{A. PENDAHULUAN}

Perusahaan didirikan memiliki tujuan yang jelas dan tercantum dalam visi dan misi. Tujuan didirikannya suatu perusahaan menurut Corelli (2018) adalah memaksimalkan nilai perusahaan itu sendiri. Memaksimalkan yang dimaksud adalah kesesuaian antara kepentingan pemegang saham (investor) untuk diri sendiri dan di dalamnya juga terdapat pilihan terbaik 
untuk perusahaan. Sebelum melakukan investasi, calon pemegang saham akan melakukan prediksi dalam melihat nilai perusahaan yang tercermin pada harga saham yang bertujuan untuk memperoleh return tinggi (Isti'adah, 2015). Pernyataan tersebut didukung oleh Chasanah (2018) di mana nilai perusahaan akan memengaruhi tingkat pengembalian investor dalam bentuk dividen.

Perolehan nilai perusahaan yang maksimal tidak akan terjadi apabila perusahaan tidak memiliki perencanaan yang baik untuk kegiatan operasinya (Brigham, 2017). Rencana ini dilakukan dengan melihat proyeksi keuangan yang tercantum dalam laporan keuangan perusahaan yakni dengan memperkiraan sumber pendanaan perusahaan (Brigham, 2017). Pernyataan tersebut didukung oleh Aamir et al. (2013) yang mengungkapkan salah satu hal penting dalam melakukan pengelolaan keuangan adalah mengenai pembiayaan perusahaan yang akan berdampak pada kekayaan perusahaan. Dengan demikian, dapat disimpulkan bahwa keputusan pendanaan merupakan salah satu faktor penting perusahaan guna mengelola perusahaan sekaligus bahan pertimbangan para investor dalam menanamkan modalnya. Struktur modal yang optimal dapat berdampak pada peningkatan nilai serta kekayaan perusahaan. Struktur modal didefinisikan sebagai bentuk gambaran proporsi keuangan perusahaan terdiri atas hutang jangka panjang dan modal sendiri sebagai sumber pembiayaan suatu perusahaan (Irham, 2017).

Teori struktur modal pertama kali diperkenalkan oleh Modigliani \& Merton, (1985) di mana aspek yang menjadi fokus dalam mengoptimalkan struktur modal dibiayai oleh leverage. Namun, pada tahun 1984 terjadi perubahan mengenai bagaimana sumber pembiayaan yang dipilih oleh perusahaan mengenai struktur modalnya. Dengan adanya perubahan aspek yang awalnya hanya mengenai hutang atau tingkat leverage kemudian membahas mengenai sumber pembiayaan mana yang lebih tepat, mengundang peneliti ingin melakukan penelitian lebih spesifik terkait faktor-faktor mana saja yang memengaruhi struktur modal agar menjadi optimal. Shil et al. (2019) mengungkapkan struktur modal perusahaan dipengaruhi oleh faktor internal dan eksternal perusahaan. Faktor internal perusahaan terdiri dari profitabilitas, ukuran, umur, likuiditas, berwujud, dan lain sebagainya. Sedangkan faktor eksternal perusahaan yang memengaruhi struktur modal adalah inflasi, suku bunga, dan kebijakan moneter.

Fenomena gap saat ini adalah penambahan hutang dijadikan salah satu faktor dalam menunjang produktivitas di mana berdasarkan Kemenkeu (2017) penambahan hutang sebesar Rp 556,5 triliun pada tahun 2015-2017 yang semula hanya Rp 609,5 triliun menjadi Rp 1.166 triliun. Selain itu Indonesia masuk ke dalam daftar 10 negara berpendapatan menengah rendah 
dengan hutang luar negeri terbanyak (Audriene, 2020). Berdasarkan kajian literatur dan fenomena gap yang telah diuraikan, di mana struktur modal akan memengaruhi nilai perusahaan maka peneliti mengambil variabel internal perusahaan yakni profitabilitas, struktur aktiva sebagai aset berwujudnya, likuiditas, serta ukuran perusahaan. Variabel tersebut dipilih dengan alasan dapat menunjang tingkat produktivitas perusahaan sebagaimana yang dimaksud Kemenkeu (2017) yang memanfaatkan hutang untuk menunjang produktivitas perusahaan.

Selain fenomena gap yang telah disampaikan mengenai struktur modal, selanjutnya terdapat inkonsistensi hasil penelitian terdahulu. Chandra (2017) mengungkapkan variabel yang memengaruhi struktur modal adalah ukuran perusahaan dan profitabilitas sedangkan untuk likuiditas tidak berpengaruh terhadap struktur modal. Berbeda dengan hasil penelitian oleh Yudhiarti et al. (2016) di mana likuiditas berpengaruh terhadap struktur modal. Kemudian, hasil penelitian Anggun et al. (2015) menunjukkan ukuran perusahaan tidak memiliki pengaruh terhadap struktur modal. Margaretha \& Zai (2013) menyatakan ukuran perusahaan, likuiditas, fleksibilitas keuangan, struktur aktiva, pertumbuhan, profitabilitas memiliki pengaruh signifikan terhadap struktur modal. Sedangkan penelitian yang dilakukan oleh Andika \& Sedana (2019) mengungkapkan bahwa profitabilitas tidak berpengaruh terhadap struktur modal. Hasil penelitian ini juga didukung oleh As'ari (2017) profitabilitas tidak berpengaruh terhadap struktur modal, sedangkan struktur aktiva berpengaruh terhadap struktur modal.

Berdasarkan fenomena gap dan research gap maka peneliti tertarik untuk melakukan penelitian mengenai faktor-faktor yang memengaruhi struktur modal ditinjau dari variabel profitabilitas, struktur aktiva, likuiditas, dan ukuran perusahaan dengan sampel penelitian pada perusahaan pertambangan yang terdaftar di Bursa Efek Indonesia periode 2014-2018. Sektor ini dipilih dengan alasan perusahaan yang bergerak dalam sektor pertambangan memiliki modal yang besar untuk memulai bisnisnya. Sektor pertambangan memiliki banyak aktiva berwujud yang nilainya besar pula. Selanjutnya, untuk melakukan kegiatan operasi sektor pertambangan membutuhkan banyak sumber pendanaan eksternal. Selain itu, berdasarkan Pusparisa (2019) mengungkapkan 10 perusahaan pemberi dividen terbesar salah satunya adalah Bukit Asam. Pembagian dividen ini apabila ditinjau dari aspek struktur modalnya, perusahaan yang memiliki perencanaan pembiayaan yang optimal maka akan berdampak pada tingkat pengembalian investasi (Isti'adah, 2015). Melihat pertumbuhan bisnis berdasarkan masing-masing sektor yang terdaftar di BEI dimuat dalam Gambar 1.

Gambar 1 memberikan informasi mengenai pertumbuhan bisnis di sektor pertambangan yang mengalami penurunan selama periode 2018 sebagian besar mengalami penurunan di 
mana pertumbuhan bisnisnya justru menurun sebesar $14,94 \%$. Dengan adanya fenomena ini juga dapat disimpulkan bahwa pernyataan satu perusahaan tidak dapat mewakilkan keseluruhan pertumbuhan bisnis berdasarkan sektornya masing-masing.

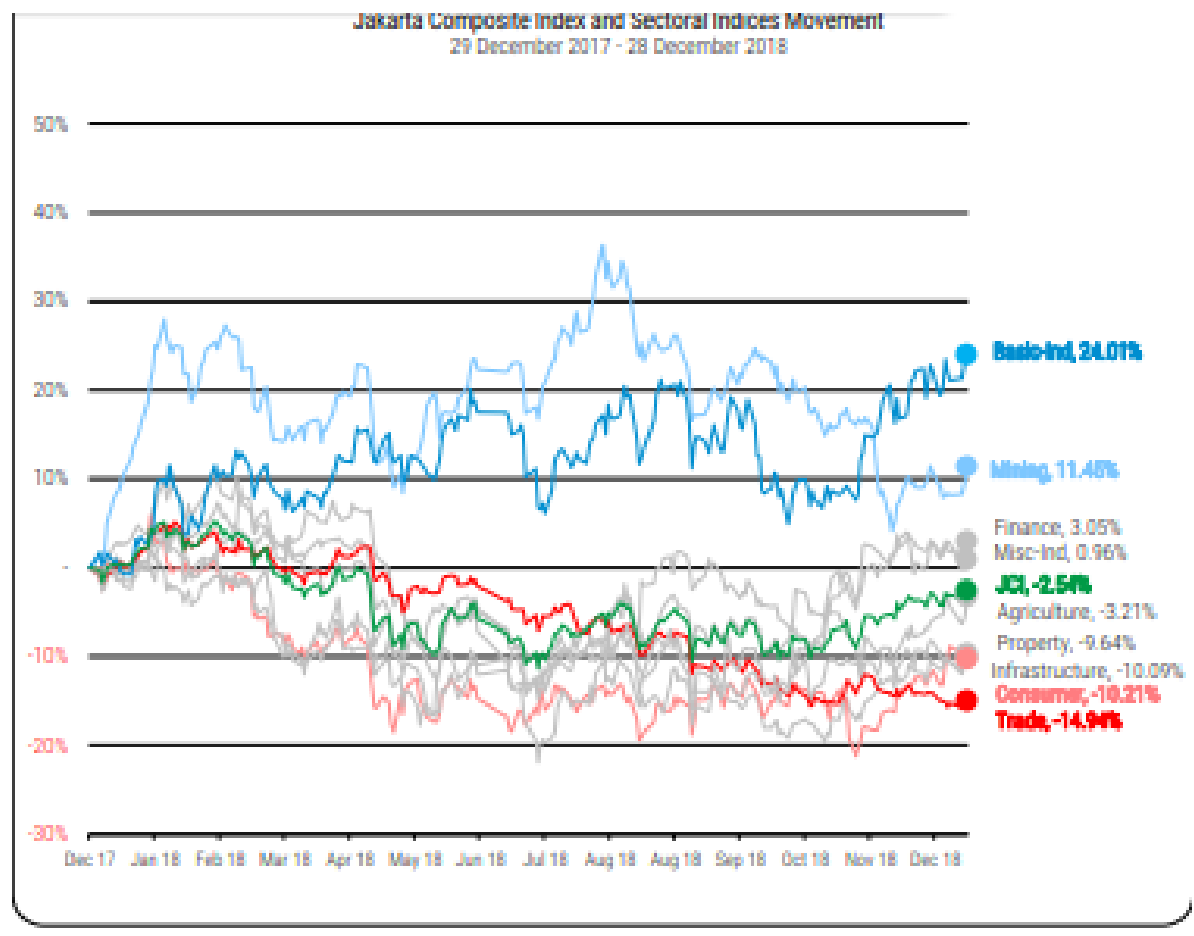

Sumber: Indonesia Stock Exchange, 2018.

Gambar 1. Pertumbuhan bisnis perusahaan berdasarkan jenis sektor

\section{B. TELAAH PUSTAKA}

Brigham \& Ehrhar (2017) mengungkapkan terdapat tiga teori yang terkait dengan struktur modal. Teori yang pertama adalah Trade Off Theory. Teori ini menunjukan struktur modal yang optimal didalamnya melibatkan pajak sebagai bentuk penambahan laba (Sewart C. Myres, 1984). Dalam teori ini, para perusahaan yang memiliki tingkat profitabilitas tinggi akan berusaha mengurangi pajaknya dengan cara meningkatkan rasio hutangnya, sehingga tambahan utang tersebut akan mengurangi pajak di mana terdapat pembayaran beban bunga atas pinjaman.

Teori yang kedua adalah Pecking Order Theory. Teori ini menyatakan bahwa perusahaan yang memiliki tingkat keuntungan yang tinggi justru rasio hutangnya akan rendah. Dalam pengertian ini berarti perusahaan menggunakan dana internalnya sebagai pembiayaan atas kegiatan operasi perusahaan.

Teori yang ketiga adalah Signalling Theory. Teori ini membahas mengenai bagaimana seharusnya sinyal-sinyal keberhasilan atau kegagalan manajemen (sebagai agen) disampaikan 
kepada pemilik (sebagai principal). Teori sinyal menjelaskan bahwa pemberian sinyal dilakukan oleh manajemen untuk mengurangi ketidakseimbangan antara informasi yang dimiliki oleh agen dengan principal.

Struktur modal dipengaruhi oleh beberapa faktor internal seperti yang telah diuraikan pada pendahuluan. Berdasarkan hasil penelitian sebelumnya yang mengungkapkan mengenai faktor-faktor yang memengaruhi struktur modal diantaranya adalah profitabilitas, struktur aktiva, likuiditas, dan ukuran perusahaan.

Profitabilitas memengaruhi struktur modal dengan alasan semakin besar jumlah keuntungan yang diperoleh perusahaan maka akan meningkatkan sumber pendanaan internal perusahaan (Irham, 2017). Profitabilitas didefinisikan sebagai salah satu kemampuan perusahaan dalam menghasilkan sebuah laba sekaligus sebagai salah satu indikator pengukuran tingkat pengembalian atas investasi yang telah dilakukan (Sukamulja, 2019). Dengan demikian, dapat disimpulkan apabila perusahaan memiliki tingkat profitabilitas yang tinggi memungkinkan tingkat pengembalian investasi juga tinggi. Dan sebaliknya, apabila tingkat profitabilitas rendah maka dapat disimpulkan laba yang diperoleh juga rendah.

Profitabilitas berpengaruh terhadap struktur modal. Apabila ditinjau dari teori trade off dan pecking order perusahaan yang memiliki kemampuan menghasilkan laba yang tinggi maka akan meningkatkan komposisi dana internal perusahaan sesuai. Bukan itu saja, apabila dianalisis lebih lanjut, profitabilitas juga akan menarik investor maupun kreditor dalam melakukan pemberian kredit maupun investasi. Teori trade off perusahaan yang memiliki tingkat profitabilitas tinggi cenderung akan meningkatkan rasio hutangnya (Stewart, 1984). Hasil penelitian dari Chandra (2017), Margaretha \& Zai (2013), Deviani \& Sudjarni (2018), Dewiningrat \& Mustanda (2018), Prastika \& Candradewi (2019) menunjukkan profitabilitas berpengaruh terhadap struktur modal. Dengan demikian, peneliti membuat hipotesis pertama sebagai berikut:

$\mathrm{H}_{1}$ : Profitabilitas berpengaruh terhadap struktur modal.

Struktur aktiva merupakan gambaran keseluruhan kekayaan perusahaan yang terdiri atas aktiva lancar dan aktiva tidak lancar (Winahyuningsih et al., 2011). Aktiva tidak lancar terdiri dari investasi jangka panjang, aktiva tetap, serta aktiva berwujud. Aktiva lancar mempunyai pengaruh terhadap struktur modal apabila ditinjau dari teori trade off di mana perusahaan lebih mengutamakan sumber dana yang berasal dari hutang (Brigham \& Ehrhar., 2017). Struktur aktiva dikaitkan dengan pemerolehan modal yang bersumber dari hutang. Menurut As'ari (2017) perusahaan yang memiliki kekayaan berwujud banyak akan memungkinkan untuk 
mendapatkan pinjaman yang semakin banyak pula. Pinjaman yang diperoleh didasarkan pada aktiva berwujud maupun aktiva tetap dapat dijadikan sebagai jaminan atas pemerolehan hutang perusahaan. Pernyataan tersebut didukung oleh Shil et al. (2019) aset tetap maupun berwujud dapat digunakan sebagai peningkatan hutang dan mengurangi masalah keagenan.

Apabila ditinjau dari signalling theory manajer sebagai agent akan mempunyai informasi yang lebih banyak daripada para pemegang saham (principal). Struktur aktiva dengan aktiva berwujud dapat mengurangi masalah asimetri informasi di mana pemeroleh pembiayaan berasal dari hutang dengan jaminan aktiva akan diketahui dan dilaporkan secara jelas kepada para pemegang saham. Hasil penelitian yang dilakukan oleh Margaretha \& Zai (2013), As'ari (2017), Anggun et al. (2015), Dewiningrat \& Mustanda (2018), Prastika \& Candradewi (2019), Ambarsari \& Hermanto (2017), Ketut \& Indah (2018), menunjukkan bahwa struktur aktiva berpengaruh terhadap struktur modal. Dengan demikian, peneliti membuat hipotesis kedua sebagai berikut:

$\mathrm{H}_{2}$ : Struktur aktiva berpengaruh terhadap struktur modal.

Likuiditas didefinisikan sebagai suatu kemampuan perusahaan dalam melunasi kewajiban jangka pendeknya secara tepat waktu (Irham, 2017). Yudhiarti et al. (2016) mengungkapkan perusahaan dengan tingkat likuiditasnya tinggi maka akan semakin mudah dalam memperoleh pendanaan. Pernyataan tersebut didukung oleh Ambarsari \& Hermanto (2017) di mana rasio likuiditas dapat digunakan untuk menganalisis kredit. Apabila ditinjau dari teori pecking order, sebuah perusahaan memiliki likuiditas yang lebih tinggi, mereka mampu membayar kewajiban jangka pendeknya dengan pembiayaan internal. Teori ini juga mengungkapkan apabila tingkat likuiditas tinggi perusahaan cenderung akan mengurangi sumber pembiayaan yang berasal dari hutang (Deviani \& Sudjarni, 2018). Hasil penelitian yang dilakukan oleh Deviani \& Sudjarni (2018), Anggun et al. (2015), Ambarsari \& Hermanto (2017), menunjukkan bahwa likuiditas berpengaruh terhadap struktur modal. Maka hipotesis penelitian ini adalah:

$\mathrm{H}_{3}$ : Likuiditas berpengaruh terhadap struktur modal.

Ukuran perusahaan atau yang biasa disebut dengan size diatur dalam UU No. 20 (2008). Undang-undang ini menjelaskan kategori ukuran perusahaan yang dilihat dari total penjualan dan aset perusahaan. Total penjualan mengidentifikasi kemampuan perusahaan dalam menjual produknya guna mendapatkan profitabilitas yakni laba atas kegiatan operasi perusahaan. Ukuran perusahaan juga akan memengaruhi tingkat kepercayaan para investor dan kreditor dalam menginvestasikan modal serta pemberian hutang yang berdampak pada kekuatan 
finansial perusahaan (Zulaecha, 2017). Oleh karena itu, semakin besar total aktiva maupun pendapatan penjualan maka semakin besar pula kategori ukuran perusahaan (Ambarsari \& Hermanto, 2017).

Ditinjau dari teori pecking order dan trade off apabila perusahaan memiliki total aset yang banyak maka akan memudahkan dalam pemerolehan pinjaman berupa hutang. Sedangkan apabila perusahaan memperoleh total pendapatan atas penjualan mengidentifikasi laba yang didapat akan semakin besar yang akan berdampak pada tingkat pembiayaan internal perusahaan. Penelitian yang dilakukan oleh Margaretha \& Zai (2013), Fahmi (2017), Megarsari (2020), menunjukkan ukuran perusahaan memiliki pengaruh kepada struktur modal. Oleh karena itu, peneliti membuat dugaan sementara, yakni:

$\mathrm{H}_{4}$ : Ukuran perusahaan berpengaruh terhadap struktur modal.

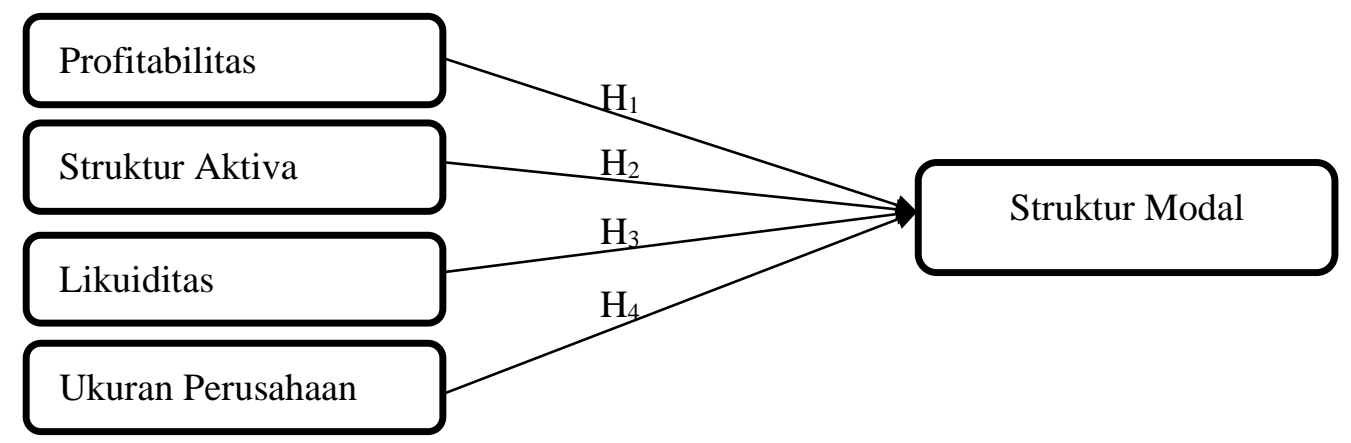

Sumber: Penelitian terdahulu yang dipublikasikan.

Gambar 2. Kerangka Konseptual Penelitian

\section{METODE PENELITIAN}

Penelitian ini dilakukan pada perusahaan sektor pertambangan dengan alasan perkembangan pertumbuhan mengalami penurunan pada tahun 2018. Selain hal itu, pada sektor pertambangan membutuhkan banyak sumber pembiayaan yang berasal dari eksternal perusahaan. Seperti yang telah diuraikan dalam pendahuluan, sektor ini juga memiliki aktiva berwujud yang cukup besar guna menunjang kegiatan operasi perusahaan. Sebagai objek penelitian di mana data yang digunakan berupa data sekunder yang diperoleh dari Bursa Efek Indonesia atau Indonesia Stock Exchange (2018) dengan alasan sebagai berikut: 1) Bursa Efek Indonesia (BEI) merupakan satu-satunya bursa efek yang ada di Indonesia yang memperdagangkan surat berharga paling lengkap; 2) Data yang tersedia di BEI lengkap dan mudah diperoleh melalui situs resminya; 3) Data di BEI akurat dan dapat dipertanggungjawabkan. 


\section{Metode Pengukuran}

\section{Struktur Modal}

Debt to asset ratio (DAR) digunakan untuk mengukur persentase liabilitas terhadap total aset perusahaan. Rasio ini penting digunakan untuk mengukur rasio bisnis, semakin tinggi nilai DAR maka risiko bisnis pun semakin tinggi, karena pendanaan aset dengan liabilitas lebih besar.

\section{Debt to asset ratio= Total debt/total asset}

\section{Profitabilitas}

Return on asset (ROA) digunakan untuk mengukur kemampuan perusahaan dalam memperoleh laba bersih dari seluruh aset yang dimiliki dan juga digunakan untuk mengukur tingkat pengembalian atas investasi perusahaan. ROA merupakan perbandingan antara laba bersih dengan modal sendiri.

ROA $=$ Laba bersih/total aktiva X 100\%

\section{Struktur Aktiva}

Struktur aktiva (SA) menggambarkan sebagian jumlah aset yang dapat dijadikan jaminan (collateral value of assets).

$\mathrm{SA}=$ Aktiva tetap/total aktiva X $100 \%$

\section{Likuiditas}

Rasio likuiditas yang digunakan adalah current ratio di mana perusahaan dapat melunasi kewajiban jangka pendeknya dengan pengelolaan aset lancar yang dimilikinya. Apabila perusahaan memiliki nilai current ratio yang tinggi menandakan perusahaan semakin likuid dan memiliki risiko kredit yang rendah di mana perusahaan memiliki kemampuan yang baik dalam melunasi kewajiban jangka pendeknya. Namun, apabila terlalu tinggi juga tidak baik dikarenakan banyak aset lancar yang menganggur.

Current ratio $=$ Aset lancar/hutang lancar X 100\%

\section{Ukuran Perusahaan (Size)}

Merupakan cerminan besar kecilnya perusahaan yang tampak dalam total aktiva perusahaan pada neraca setiap tahun periode berjalan. Ukuran yang digunakan adalah logaritma natural dari total aktiva.

Ukuran perusahaan = Logaritma natural (total aset) X $100 \%$

\section{Populasi dan Sampel}

Populasi merupakan sebagai wilayah generalisasi terdiri atas objek atau subjek yang mempunyai kualitas serta karakteristik tertentu yang diterapkan oleh peneliti untuk dipelajari 
serta akan ditarik kesimpulan. Dalam penelitian ini populasinya adalah perusahaan pertambangan yang terdaftar di BEI sebanyak 50 perusahaan. Sedangkan sampel adalah sebagian dari populasi (Sugiyono, 2017).

\section{Teknik Pengumpulan Data}

Teknik dalam penelitian ini menggunakan teknik non-probability sampling dengan purposive sampling. Purposive Sampling didefinisikan sebagai suatu teknik pengambilan sampel sumber data dengan pertimbangan berdasarkan kriteria-kriteria tertentu. Kriteria penarikan sampel yang digunakan dalam penelitian yaitu: 1) Perusahaan pertambangan yang konsisten atau secara berturut-turut mencatatkan sahamnya di Bursa Efek Indonesia periode 2014-2018; 2) Perusahaan yang mampu menghasilkan laba berturut-turut pada tahun 20142018; 3) Perusahaan pertambangan yang memiliki memiliki data lengkap terkait variabel penelitian, yakni DAR, ROA, SA, current ratio, dan Ln (aset); 4) Laporan keuangan dinyatakan dalam Dolar. Sampel penelitian ini adalah perusahaan pertambangan yang terdaftar di BEI yang memenuhi kriteria pengambilan sampel sebanyak 10 perusahaan. Daftar perusahaan yang dijadikan sampel bisa terlihat dari Tabel 1 .

Tabel 1. Sampel Penelitian

\begin{tabular}{lll}
\hline No & Kode & \multicolumn{1}{c}{ Nama Perusahaan } \\
\hline 1 & ADRO & Adaro Tbk \\
2 & BSSR & Baramulti Suksessarana \\
3 & DEWA & Darma Henwa \\
4 & ITMG & Indo Tambang Megah \\
5 & KKGI & Resources Alam Tbk \\
6 & MYOH & Samindo Resources \\
7 & ESSA & Surya Eka Perkasa \\
8 & TOBA & Toba Bara Sejahtera \\
9 & PSAB & J Resources \\
10 & MBAP & Mitrabara \\
\hline \multicolumn{3}{c}{ Sumber: Data diolah penulis (2019). }
\end{tabular}

\section{Teknik Analisis Data}

Pada penelitian ini data diuji menggunakan regresi linier berganda. Regresi linier berganda merupakan alat statistik yang berfungsi untuk mengetahui pengaruh dua atau lebih variabel bebas terhadap satu variabel terikat (Ghozali, 2016). Pengujian data pertama dilakukan asumsi klasik, meliputi uji normalitas, uji autokorelasi, uji multikolinearitas, dan uji heteroskedastisitas. Selanjutnya untuk memastikan terdapat pengaruh secara simultan atau maupun parsial maka akan dilakukan uji t dan uji f. Persamaan regresi linier berganda adalah sebagai berikut: 


\begin{tabular}{cr}
\hline $\begin{array}{l}\text { ISSN 2623-0690 (Cetak) } \\
\text { 2655-3813 (Online) }\end{array}$ & $\begin{array}{r}\text { Business Management Analysis Journal (BMAJ) } \\
\text { Vol. } 4 \text { No. } 1 \text { April } 2021\end{array}$ \\
\hline$Y=a+b_{1} X_{1}+b_{2} X_{2}+b_{2} X_{3}+b_{2} X_{4}+e$ &
\end{tabular}

Keterangan :

$\begin{array}{ll}\mathrm{Y} & =\text { Struktur modal } \\ \mathrm{a} & =\text { Konstanta } \\ \mathrm{b}_{1} \cdot \mathrm{b}_{2} \cdot \mathrm{b}_{3} \cdot \mathrm{b}_{4} & =\text { Koefisien regresi } \\ \mathrm{X}_{1} & =\text { Profitabilitas } \\ \mathrm{X}_{2} & =\text { Struktur aktiva } \\ \mathrm{X}_{3} & =\text { Likuiditas } \\ \mathrm{X}_{4} & =\text { Ukuran perusahaan } \\ \mathrm{e} & =\text { Standard error }\end{array}$

\section{HASIL DAN PEMBAHASAN}

\section{Asumsi Klasik}

\section{Uji Multikolinieritas}

Uji ultikolinieritas bertujuan untuk menguji model regresi penelitian apakah ditemukan adanya hubungan atau korelasi antar variabel dependen dengan melihat nilai variance inflation factor (VIF). Hasil perhitungan VIF kurang dari 10. Tabel 2 mengenai uji multikolinieritas menunjukkan tidak ada variabel yang nilai VIF-nya di atas 10, sehingga dapat disimpulkan bahwa tidak terjadi multikolinieritas.

Tabel 2. Uji Multikolinieritas

Coefficients $^{\mathrm{a}}$

\begin{tabular}{|c|c|c|c|c|c|c|c|c|}
\hline \multirow{2}{*}{\multicolumn{2}{|c|}{ Model }} & \multicolumn{2}{|c|}{$\begin{array}{l}\text { Unstandardized } \\
\text { Coefficients }\end{array}$} & \multirow{2}{*}{$\begin{array}{c}\begin{array}{c}\text { Standardized } \\
\text { Coefficients }\end{array} \\
\text { Beta } \\
\end{array}$} & \multirow{2}{*}{$\mathbf{t}$} & \multirow{2}{*}{ Sig. } & \multicolumn{2}{|c|}{$\begin{array}{l}\text { Collinearity } \\
\text { Statistics }\end{array}$} \\
\hline & & B & $\begin{array}{c}\text { Std. } \\
\text { Error }\end{array}$ & & & & $\begin{array}{c}\text { Toleran } \\
\text { ce }\end{array}$ & VIF \\
\hline \multirow[t]{5}{*}{1} & (Constant) &,- 200 & 1,324 & &,- 151 & 881 & & \\
\hline & Profitabilitas & 1,479 & 2,657 &, 051 & ,557 & ,581 & ,287 & 3,481 \\
\hline & Struktur Aktiva & 1,069 & 072 & ,936 & 14,954 &, 000 & ,626 & 1,598 \\
\hline & Likuiditas &,- 120 & 081 &,- 086 & $-1,477$ &, 147 & ,725 & 1,379 \\
\hline & Ukuran Perusahaan &, 026 & 065 & ,040 & ,409 & ,684 & 251 & 3,980 \\
\hline
\end{tabular}

1. Dependent Variable: Struktur Modal

Sumber: Data diolah penulis menggunakan SPSS 23 (2021)

\section{Uji Autokorelasi}

Bertujuan untuk menguji model regresi linier ada kesalahan pengganggu pada periode $\mathrm{t}$ dengan kesalahan pengganggu pada periode sebelumnya atau t-1. Berdasarkan pada Tabel 3 nilai Durbin Watson adalah sebesar 1,743. Kemudian dibandingkan dengan nilai dari tabel 
Durbin watson dengan tingkat signifikansi 5\% $(\mathrm{a}=0,05)$, apabila tidak terdapat korelasi maka nilai dari $\mathrm{dU}<\mathrm{d}<4-\mathrm{dU} . \mathrm{N}=50 ; \mathrm{k}=4 ; \mathrm{dL}=1,7214 ; \mathrm{dU}=1,3346 ; 4-\mathrm{dU}=4-1,3346=2,6654$. Maka dapat disimpulkan bahwa 1,3346 < 1,743 $<2,6654$ yang memiliki arti bahwa model regresi ini terdapat gejala korelasi.

Tabel 3. Uji Autokorelasi

Model Summary ${ }^{\mathrm{b}}$

\begin{tabular}{lrrrrr}
\hline Model & R & R Square & $\begin{array}{c}\text { Adjusted R } \\
\text { Square }\end{array}$ & $\begin{array}{c}\text { Std. Error of } \\
\text { the Estimate }\end{array}$ & Durbin-Watson \\
\hline 1 &, $943^{\mathrm{a}}$ &, 890 &, 880 &, 45257 & 1,743 \\
\hline
\end{tabular}

a. Predictors: (Constant), Ukuran Perusahaan, Struktur Aktiva, Likuiditas,

Profitabilitas

b. Dependent Variable: Struktur Modal

Sumber: Data diolah penulis menggunakan SPSS 23 (2021)

\section{Uji Normalitas}

Hasil uji normalitas dapat dilihat pada Tabel 4 di mana residual dengan menggunakan One Sample Kolmogorov dengan hasil sebesar nilai signifikansi 0,000. Nilai signifikansi 0,000>0,05 sehingga disimpulkan nilai residual berdistribusi normal.

Tabel 4. Uji Normalitas

One-Sample Kolmogorov-Smirnov Test

\begin{tabular}{llr}
\hline & & $\begin{array}{c}\text { Unstandardized } \\
\text { Residual }\end{array}$ \\
\hline $\mathrm{N}$ & Mean & 50 \\
Normal Parameters & a,b &, 0000000 \\
& Std. &, 43370516 \\
Most Extreme & Deviation &, 228 \\
Differences & Absolute &, 228 \\
& Positive &,- 154 \\
Test Statistic & Negative &, 228 \\
Asymp. Sig. (2-tailed) & &, $000^{\mathrm{c}}$ \\
\hline
\end{tabular}

a. Test distribution is Normal.

b. Calculated from data.

c. Lilliefors Significance Correction.

Sumber: Data diolah penulis menggunakan SPSS 23 (2021).

\section{Uji Heteroskedasitas}

Tabel 5 memuat hasil uji glejser yang digunakan untuk mendeteksi masalah heteroskedastisitas pada model regresi dan ditunjukan dengan nilai signifikansi variabel secara statistik. Hasil uji menunjukan bahwa nilai struktur aktiva sebesar 0,009. Sementara untuk lulus dari uji heteroskedastisitas nilai signifikansi untuk masing-masing variabel adalah lebih dari 
nilai a $(0,05)$. Dengan demikian, dapat disimpulkan bahwa model regresi ini terdapat gejala heteroskedastisitas.

Tabel 5. Uji Heteroskedasitas

Coefficients $^{\mathrm{a}}$

\begin{tabular}{|c|c|c|c|c|c|c|}
\hline & \multirow[t]{2}{*}{ Model } & \multicolumn{2}{|c|}{ Unstandardized Coefficients } & \multirow{2}{*}{$\begin{array}{c}\begin{array}{c}\text { Standardized } \\
\text { Coefficients }\end{array} \\
\text { Beta } \\
\end{array}$} & \multirow[t]{2}{*}{$\mathbf{t}$} & \multirow[t]{2}{*}{ Sig. } \\
\hline & & $\mathbf{B}$ & Std. Error & & & \\
\hline \multirow[t]{5}{*}{1} & (Constant) &, 034 & ,959 & &, 036 & 972 \\
\hline & Profitabilitas & 013 & 1,924 &, 002 & 007 & ,995 \\
\hline & Struktur aktiva & , 142 &, 052 & ,438 & 2,750 & 009 \\
\hline & Likuiditas &,- 087 & ,059 &,- 219 & $-1,478$ &, 146 \\
\hline & Ukuran perusahaan & 013 & 047 &, 072 & ,288 &, 775 \\
\hline
\end{tabular}

a. Dependent Variable: RES2

Sumber: Data diolah penulis menggunakan SPSS 23 (2021).

\section{Weighted Least Square (WLS)}

WLS merupakan metode penyembuhan dalam uji heteroskedasitas agar terbebas dari gejala heteroskedasitas. WLS dilakukan dengan mengkuadratkan variabel independen yang terdapat gejala heteroskedasitas, yakni struktur aktiva, kemudian semua variabel dibagi dengan variabel yang dikuadratkan.

Tabel 6. Weighted Least Square (WLS)

Coefficients $^{\mathrm{a}}$

\begin{tabular}{|c|c|c|c|c|c|c|}
\hline & \multirow[t]{2}{*}{ Model } & \multicolumn{2}{|c|}{ Unstandardized Coefficients } & \multirow{2}{*}{$\begin{array}{c}\begin{array}{c}\text { Standardized } \\
\text { Coefficients }\end{array} \\
\text { Beta } \\
\end{array}$} & \multirow[t]{2}{*}{$\mathbf{t}$} & \multirow[t]{2}{*}{ Sig. } \\
\hline & & B & Std. Error & & & \\
\hline \multirow[t]{5}{*}{1} & (Constant) & 1,152 & ,502 & & 2,295 &, 026 \\
\hline & TRANSFORM_X 1 &,- 275 &, 228 &,- 184 & $-1,207$ & ,234 \\
\hline & TRANSFORM_X ${ }_{2}$ &,- 053 & 067 &,- 117 &,- 787 & ,435 \\
\hline & TRANSFORM_X 3 &, 015 & ,016 & ,236 & ,910 & ,367 \\
\hline & TRANSFORM_X & ,000 & ,002 & ,068 & ,274 & ,785 \\
\hline
\end{tabular}

a. Dependent Variable: ABS_RES

Sumber: Data diolah penulis menggunakan SPSS 23 (2021).

\section{Uji Hipotesis}

Uji hipotesis dilakukan untuk mengetahui pengaruh secara parsial maupun simultan pada koefisien determinasi, uji f dan uji t yang dijelaskan sebagai berikut:

\section{Uji t}

Uji t bertujuan untuk mengetahui pengaruh masing-masing variabel independen terhadap variabel dependen. Uji t dalam penelitian ini dilakukan secara terpisah menggunakan satu demi satu pengujian tiap-tiap variabel independen terhadap variabel dependen. Penelitian ini mengacu pada tingkat nilai signifikansi $\mathrm{a}=0,05$. Hipotesis diterima apabila nilai sig. $<0,05$ 
dan sebaliknya. Pada Tabel 7 mengenai Uji t diperoleh informasi bahwa struktur aktiva dan likuiditas memengaruhi struktur modal dengan nilai signifikansi sebesar 0,000 $<0,05$ dan $0,040<0,05$. Sehingga $\mathrm{H}_{2}$ dan $\mathrm{H}_{3}$ diterima artinya struktur aktiva dan likuiditas berpengaruh terhadap struktur modal. Sedangkan nilai signifikansi profitabilitas dan ukuran perusahaan sebesar 0,303 > 0,05 serta 0,357>0,05. Disimpulkan bahwa $\mathrm{H}_{1}$ dan $\mathrm{H}_{4}$ ditolak, artinya profitabilitas dan ukuran perusahaan tidak berpengaruh terhadap struktur modal.

Tabel 7. Uji T

Coefficients $^{\mathrm{a}}$

\begin{tabular}{lrrrrr}
\hline \multirow{2}{*}{ Model } & \multicolumn{1}{c}{ Unstandardized Coefficients } & $\begin{array}{c}\text { Standardized } \\
\text { Coefficients }\end{array}$ & \multirow{2}{*}{$\mathbf{t}$} & \multirow{2}{*}{ Sig. } \\
\cline { 2 - 5 } & \multicolumn{1}{c}{ B } & Std. Error & \multicolumn{1}{c}{ Beta } & & \\
\hline Profitabilitas & $-4,278$ & 4,106 &,- 149 & $-1,042$ &, 303 \\
Struktur aktiva & 1,073 &, 057 &, 938 & 18,795 &, 000 \\
Likuiditas &,- 408 &, 193 &,- 291 & $-2,109$ &, 040 \\
Ukuran perusahaan &,- 087 &, 094 &,- 133 &,- 929 &, 357 \\
\hline
\end{tabular}

a. Dependent Variable: Struktur Modal

Sumber: SPSS 23, Diolah (2021).

\section{Uji F}

Untuk melihat signifikansi dari hasil uji $\mathrm{F}$, maka nilai sig. harus $<0,05$ dan nilai $\mathrm{f}$ hitung harus > f tabel. Melihat hasil uji F (Tabel 8) maka dapat ditarik kesimpulan nilai sig. sebesar $0,000<0,05$, dengan nilai $\mathrm{f}$ hitung $(90,8327)>\mathrm{f}$ tabel $(2,578)$ sehingga variabel profitabilitas, struktur aktiva, likuiditas, dan ukuran perusahaan berpengaruh terhadap struktur modal serta penelitian layak dilakukan.

Tabel 8. Uji F

ANOVA $^{\mathrm{a}}$

\begin{tabular}{llrrrrr}
\hline Model & $\begin{array}{c}\text { Sum of } \\
\text { Squares }\end{array}$ & df & $\begin{array}{c}\text { Mean } \\
\text { Square }\end{array}$ & \multicolumn{1}{c}{ F } & \multicolumn{1}{c}{ Sig. } \\
\hline 1 & Regression & 74,413 & 4 & 18,603 & 90,827 &, $000^{\mathrm{b}}$ \\
& Residual & 9,217 & 45 &, 205 & & \\
& Total & 83,630 & 49 & & & \\
\hline
\end{tabular}

a. Dependent Variable: Struktur Modal

b. Predictors: (Constant), Ukuran Perusahaan, Struktur Aktiva, Likuiditas, Profitabilitas

Sumber: Data diolah penulis menggunakan SPSS 23 (2021).

\section{Pembahasan}

\section{Pengaruh Profitabilitas terhadap Struktur Modal}

Hasil penelitian menunjukan profitabilitas tidak berpengaruh terhadap struktur modal. 
Hal ini berarti bahwa dengan tingkat profitabilitas yang tinggi perusahaan akan cenderung menggunakan sumber pembiayaan dari laba ditahan daripada menggunakan hutang. Pernyataan tersebut sejalan dengan teori pecking order bahwa tingkat ROA akan mencerminkan tingkat pengembalian atau return. Pada penelitian ini tingkat ROA di sektor pertambangan sangat rendah di mana dari seluruh sampel tidak ada yang mendekati 1 (satu). Oleh karena itu, dapat disimpulkan ROA tidak berpengaruh terhadap struktur modal pada sektor perusahaan pertambangan yang terdaftar di BEI. Hasil penelitian ini didukung oleh Andika \& Sedana (2019) dan As'ari (2017).

\section{Pengaruh Struktur Aktiva terhadap Struktur Modal}

Hasil penelitian menunjukan struktur aktiva berpengaruh terhadap struktur modal. Struktur aktiva merupakan komposisi kekayaan yang dimiliki perusahaan baik berupa aktiva lancar dan aktiva tidak lancar. Aktiva tidak lancar dapat digunakan sebagai salah satu jaminan perusahaan untuk mendapatkan hutang. Sesuai dengan teori trade off perusahaan akan memaksimalkan hutang untuk mendapatkan keuntungan. Dengan demikian dapat disimpulkan perusahaan yang memiliki aktiva tetap lebih banyak akan cenderung menggunakan sumber pembiayaan yang berasal dari hutang. Penelitian ini didukung oleh Margaretha \& Zai (2013), As'ari (2017), Anggun et al. (2015), Dewiningrat \& Mustanda (2018), Prastika \& Candradewi (2019), Ambarsari \& Hermanto (2017), Ketut \& Indah (2018).

\section{Pengaruh Likuiditas terhadap Struktur Modal}

Hasil penelitian menunjukan likuiditas berpengaruh terhadap struktur modal. Likuiditas diukur menggunakan current ratio di mana semakin tinggi nilai current ratio maka semakin kecil kemungkinan perusahaan akan menggunakan hutang. Ditinjau dari teori pecking order perusahaan yang memiliki nilai current ratio tinggi diartikan bahwa perusahaan mampu membayar kewajiban jangka pendeknya dengan menggunakan aset lancarnya. Oleh karena itu, struktur modal dipengaruhi oleh likuiditas. Hasil penelitian ini didukung oleh Deviani \& Sudjarni (2018), Anggun et al. (2015), Ambarsari \& Hermanto (2017).

\section{Pengaruh Ukuran Perusahaan terhadap Struktur Modal}

Dari hasil pengujian hipotesis dapat dijelaskan bahwa ukuran perusahaan tidak akan memengaruhi keputusan kreditor dalam memberikan kredit pada perusahaan sektor pertambangan. Dapat diartikan pula bertambah atau berkurangnya total aset perusahaan tidak akan berdampak terhadap minat investor maupun kreditor. Hal ini sejalan dengan pernyataan Isti'adah (2015) di mana para investor atau kreditor akan tetap mengedepankan proyeksi nilai perusahaan yang tercermin pada harga saham. Dari penelitian ini juga mendukung data yang 
dilansir oleh BEI tahun 2018 mengenai pertumbuhan bisnis sektor pertambangannya yang merosot.

\section{E. KESIMPULAN}

Penelitian mengenai struktur modal sudah banyak dilakukan oleh para peneliti sebelumnya. Namun, seiring perkembangan waktu terjadi fenomena gap serta adanya inkonsistensi hasil penelitian maka perlu melihat kembali variabel-variabel yang memengaruhi struktur modal. Penelitian ini menguraikan serta mendefinisikan mengenai faktor-faktor yang diduga memengaruhi struktur modal terdiri dari profitabilitas, struktur aktiva, likuiditas, dan ukuran perusahaan pada perusahaan sektor pertambangan yang terdaftar di BEI periode 20142018 .

Hasil penelitian menunjukkan profitabilitas serta ukuran tidak memiliki pengaruh terhadap struktur modal. Diartikan bahwa dengan adanya penambahan ukuran perusahaan serta peningkatan keuntungan tidak akan memengaruhi komposisi struktur modal yang ada di perusahaan sektor pertambangan. Sedangkan untuk variabel struktur aktiva dan likuiditas memengaruhi komposisi struktur modal. Hal ini menerangkan semakin tinggi nilai aktiva tetap perusahaan maka pemerolehan sumber dana yang bersumber dari hutang akan mudah diperoleh. Perusahaan yang memiliki tingkat likuiditas juga mengidentifikasikan kemampuan perusahaan yang baik dalam melunasi kewajiban lancarnya menggunakan aset lancar perusahaan.

Peneliti menyadari banyak keterbatasan yang ada, di mana sampel penelitian yang digunakan memiliki kemunduran kinerja sehingga data yang diperoleh untuk membuktikan hipotesis kurang tepat sasaran. Selain itu, sampel dan periode penelitian ini terbilang masih sedikit di mana hanya menggunakan 10 perusahaan dan menggunakan jangka waktu 5 tahun terakhir. Saran peneliti bagi penelitian selanjutnya adalah apabila ingin melakukan penelitian usahakan populasi yang akan dijadikan sampel penelitian mempunyai kinerja pertumbuhan bisnis yang baik. Dengan demikian data yang diperoleh untuk pengujian hipotesis akan lebih bagus pula. Selanjutnya, untuk mengakurasikan data peneliti menyarankan untuk menambahkan periode waktu penelitian, apabila sampel penelitian terbilang sedikit.

\section{DAFTAR PUSTAKA}

Aamir, Z., Gulzar, S., Uzma, F., \& Aslam, K.S. (2013). Factors affecting the capital structure in energy sector of Pakistan. International Journal of Academic Research, 5(3), 503510. 
Ambarsari, R., \& Hermanto, S.B. (2017). Pengaruh Ukuran Perusahaan, Pertumbuhan Penjualan, Profitabilitas, Struktur Aktiva, Likuiditas Terhadap Struktur Modal. Jurnal Ekonomi Dan Riset Akuntansi, 6, 1268-1289.

Andika, I.K.R., \& Sedana, I.B.P. (2019). Pengaruh Profitabilitas, Struktur Aktiva, Dan Ukuran Perusahaan,Terhadap Struktur Modal. E-Jurnal Manajemen, 8(9), 5803-5824.

Anggun, N., Listyorini, F., \& Widati, W. (2015). Analisa Profitabilitas, Likuiditas, Pertumbuhan Penjualan, Struktur Aktiva Dan Kebijakan Dividen Terhadap Struktur Modal. Prosinding Seminar Nasional Multi Disiplin Ilmu \& Call Of Paper UNISBANK, $2011,640-649$.

As'ari, H. (2017). Analisis pengaruh struktur aktiva dan profitabilitas terhadap struktur modal dan kinerja perusahaan (studi kasus pada perusahaan BUMN yang terdaftar di BEI). Jurnal Riset Akuntansi Mercu Buana, 3(2), 68.

Audriene, D. (2020, Oktober 15). Menyoal Utang yang Menumpuk dan Masyarakat Kian Melarat. CNN Indonesia. Diakses dari https://www.cnnindonesia.com/ekonomi/20201015063657-532-558560/menyoal-utangyang-menumpuk-dan-masyarakat-kian-melarat

Brigham, E., \& Ehrhar., M.C. (2017). Financial Management Theory \& Practice. Cengage Learning.

Chandra, T. (2017). Faktor-Faktor Yang Mempengaruhi Struktur Modal Pada Perusahaan Properti Dan Real Estate Di Indonesia. EKUITAS (Jurnal Ekonomi Dan Keuangan), 18(4), 507.

Chasanah, N A. (2018). Pengaruh Rasio Likuiditas, Profitabilitas, Struktur Modal Dan Ukuran Perusahaan Terhadap Nilai Perusahaan Pada Perusahaan Manufaktur Yang Terdaftar Di Bei Tahun 2015-2017. Jurnal Penelitian Ekonomi dan Bisnis, 3(1), 39-47.

Corelli, A. (2018). Analytical Corporate Finance (2 ed.). Springer Nature Switzerland AG.

Dewiningrat, A.I., \& Mustanda, I. K. (2018). Pengaruh Likuiditas, Profitabilitas, Pertumbuhan Penjualan, Dan Struktur Aset Terhadap Struktur Modal. E-Management Unud, 7(7), 3471-3501.

Fahmi, L.Z. (2017). Pengaruh Struktur Aktiva, Ukuran Perusahaan, dan Likuiditas Terhadap Struktur Modal. Jurnal Ilmu Dan Riset Akuntansi, 6(2), 780-798.

Ghozali, I. (2016). Aplikasi Analisis Multivariate dengan Program IBM SPSS 23 (8 ed.). Semarang: Badan Penerbit Universitas Diponegoro.

Indonesia Stock Exchange. (2018). IDX Statistics 2018. December, 1-206.

Irham, F. (2017). Analisis Kinerja Keuangan (4 ed.). Bandung: Alfabeta.

Isti'adah, U. (2015). Faktor-Faktor Yang Mempengaruhi Nilai Perusahaan Pada Perusahaan Manufaktur. Jurnal Nominal, IV(1), 57-72.

Kemenkeu. (2017). Utang Untuk Peningkatan Produktivitas 2012-2017. Diakses dari https://www.kemenkeu.go.id/media/9711/utang-akumulasi-dalam-periode.jpg

Ketut, N., \& Indah, N. (2018). Pengaruh Profitabilitas, Likuiditas, Struktur Aktiva Dan Kebijakan Dividen Terhadap Struktur Modal Perusahaan Manufaktur Di BEI. E- 
Manajemen Unud, 7(6), 3115-3143.

Margaretha, F., \& Zai, M. P. (2013). Faktor-Faktor Yang Mempengaruhi Kinerja Keuangan Perbankan Indonesia. Jurnal Bisnis Dan Akuntansi, 15(2), 133-141.

Megarsari, N. P. A. E. A. (2020). Pengaruh Struktur Aktiva, Perputaran Modal Kerja, Likuiditas, Dan Pendanaan Modal Kerja Terhadap Kinerja Perusahaan. Jurnal Kharisma, 2, 350-371.

Modigliani, F., \& Merton, H.M. (1985). The Cost of Capital, Corporation Finance and the Theory of Investment. The American Economic Review, 48(9), 261-297.

Prastika, N. P. Y., \& Candradewi, M. R. (2019). Pengaruh Profitabilitas, Struktur Aktiva, Dan Likuiditas Terhadap Struktur Modal Perusahaan Sub Sektor Konstruksi Bangunan Di BEI. E-Jurnal Manajemen, 8(7), 4444-4473.

Sewart C. Myres. (1984). The Capital Structure Puzzle. Journal of Finance 39(3), 574-592.

Shil, N., Hossain, M. N., \& Ullah, M.N., (2019). Exploring the underlying factors affecting capital structure decision: A quantitative analysis. Journal of Corporate Accounting \& Finance, 30(4), 69-84.

Stewart, C. M. (1984). Capital Structure Puzzle. National Bureay of Economic Research, 1393, 1-35.

Sugiyono. (2017). Metode Penelitian Kuantitatif, Kualitatif, dan $R \& D$. Bandung: Alfabeta.

Sukamulja, S. (2019). Analisis Laporan Keuangan. Yogyakarta : ANDI dan BPFE.

Undang-Undang Nomor 20 Tahun 2008 tentang Usaha Mikro, Kecil, dan Menengah.

Winahyuningsih, P., Sumekar, K., \& Prasetyo, H. (2011). Analisis Faktor-Faktor Yang Mempengaruhi Struktur Modal Pada Perusahaan Manufaktur Yang Go Public Di Bursa Efek Indonesia. Sosial dan Budaya, 4(1), 1-17.

Pusparisa, Y. (2019, Juni 4). 10 BUMN Pemberi Dividen Terbesar. Katadata. Diakses 22 September 2020, dari https://katadata.co.id/ariayudhistira/infografik/5e9a5188ef2ed/10bumn-pemberi-dividen-terbesar

Yudhiarti, R., Mohammad, D. H., \& Mahfud, K. (2016). Analisis Faktor-Faktor Yang memengaruhi Struktur Modal (Pada Perusahaan Manufaktur Yang Terdaftar Di Bursa Efek Indonesia Periode Tahun 2010-2014). Diponegoro Journal of Management, 5, 113.

Deviani, M.Y., \& Sudjarni, L. K. (2018). Pengaruh Tingkat Pertumbuhan, Struktur Aktiva, Profitabilitas , Dan Likuiditas, Terhadap Struktur Modal Perusahaan Pertambangan di BEI. E-Manajemen Unud, 7(3), 1222-1254.

Zulaecha, H. E. (2017). Kinerja BUMN di Indonesia: Kompensasi Eksekutif, Leverage, Size, dan Kepemilikan Manajerial. Agregat: Jurnal Ekonomi Dan Bisnis, 1(1), 38. 